\title{
Seagrass-associated fish species' richness: evidence to support conservation along the south coast of Lombok Island, Indonesia
}

\author{
ABDUL SYUKUR ${ }^{1,2, \boldsymbol{v}}$, AGIL AL-IDRUS ${ }^{1,2}$, LALU ZULKIFLI $^{1,2}$ \\ ${ }^{1}$ Department of Sciences Education. Faculty of Teacher Training and Education, Universitas Mataram. J1. Majapahit No. 62, Mataram 83126, West Nusa \\ Tenggara, Indonesia. Tel.: +62-370-623873, Fax.: +62-370-634918, •email: syukurbiologi @unram.ac.id \\ ${ }^{2}$ Graduate Program of Science Education. Universitas Mataram. Jl. Majapahit No. 62, Mataram 83126, West Nusa Tenggara, Indonesia
}

Manuscript received: 31 October 2020. Revision accepted: 24 January 2021.

\begin{abstract}
Syukur A, Al-Idrus A, Zulkifli L. 2021. Seagrass-associated fish species' richness: evidence to support conservation along the South Coast of Lombok Island, Indonesia. Biodiversitas 22: 988-998. The concept of seagrass conservation at a global scale tends to be less appropriate with regard to the environmental conditions at the regional and local scales, and thus, there is a need for scientific studies at the regional and local scales to support conservation measures. This research aimed to describe the importance of seagrass conservation based on the species richness of seagrass-associated fish. Data were collected from seven seagrass locations using surveys and observation. Data on the fish species present were collected with the gear used by small-scale fishermen to catch fish in the seagrass area and the surrounding waters. Data analysis was descriptive; the statistical analyses performed included calculation of the ShannonWiener index of diversity ( $\left.\mathrm{H}^{\prime}\right)$, the Simpson evenness index (E), and the Morisita species richness index (D) as well as cluster analysis. All statistical analyses were performed in IBM SPSS Statistics 25. We found 104 fish species belonging to 38 families. Leiognathidae, Apogonidae, Clupeidae, Carangidae, Channidae, Sillaginidae, and Mullidae are families with high abundance, and 16 fish species have an abundance of individuals above the average value (192 individuals) of the total number of individuals (20,352). Meanwhile, 94.37\% of the fish families are the target catch of small-scale fishermen (commercial fish). The diversity of fish species associated with seagrass in the study location is evidence of the survival of seagrass provision services at the local scale for fish. Therefore, scientific evidence of the species richness of fish, species yang domina, and its importance for small-scale fisheries at each seagrass bed in the study location can be used as a source of information for increasing and improving seagrass conservation efforts at the local scale.
\end{abstract}

Keywords: Ecological index, local scale, seagrass conservation, species richness

\section{INTRODUCTION}

Seagrass is a higher plant that thrives in oligotrophic environments (Anton et al. 2020) and plays a vital role in human wellbeing (Ambo-Rappe 2010; Nordlund et al. 2010; Cullen-Unsworth et al. 2014), especially in fishery production at the global, regional, and local scales (de la Torre-Castro et al. 2014; Nordlund et al. 2018; Unsworth et al. 2019). Conversely, essential services provide habitats and food to diverse marine life (Du et al. 2019; Moussa et al. 2020). However, seagrass status and protection rarely come under the spotlight as compared to other ecosystems in coastal areas, such as mangrove ecosystems and coral reefs (Larkum et al. 2018; Waycott et al. 2009). Meanwhile, ecological evidence indicates that $20 \%$ of commercial fish species are dependent on seagrass during their life cycle (Ambo-Rappe et al. 2013), as permanent, temporary, regular, or irregular residents. Furthermore, seagrass cover and canopy structure positively correlate with fish species' abundance (Susilo et al. 2018). Meanwhile, areas vegetated by seagrass can increase fish biomass, and the economic value per hectare has been estimated to be higher compared to areas with mangrove vegetation and tidal swamps (Jänes et al. 2020).

Seagrass is currently threatened with destruction in many places, and seagrass beds in Indonesia are under widespread threat. The implications of this can significantly impact local food supply as well as global fishery production, carbon cycling, and biodiversity conservation (Unsworth et al. 2018). The usual source of the threats is anthropogenic activity (Syukur et al. 2017), and the danger of damage is a significant challenge in conservation efforts. Obstacles in seagrass conservation efforts are as follows: (i) affirmation must be provided so that the community realizes or recognizes the importance of seagrass; (ii) data and information on the current status and condition of seagrass are not yet regular; (iii) management actions at the local scale have not taken the appropriate steps; (iv) efforts are needed to balance human needs and survival; (v) there is limited scientific research output to support conservation actions; (vi) conservation efforts are increasingly difficult in the era of climate change (Unsworth et al. 2019). Nevertheless, seagrass conservation efforts at a local scale can be achieved through affirmation and optimizing the participation of the fishing community (Jayabaskaran et al. 2018; Syukur et al. 2018). However, the available information related to seagrass damage on a local scale is minimal and inadequate.

Seagrasses, which have a vital function in supporting food security, are still widely underappreciated. This is a factor in the difficulty of preventing seagrass degradation. Another factor is the incomplete understanding of the ecosystem services provided by seagrass habitats, 
particularly those related to management in the fisheries sector. Meanwhile, the integration of bad planning on the part of the jurisdiction and sectoral management often causes the continued degradation of biodiversity and ecosystem values due to anthropogenic activities and climate change (Griffiths et al. 2020) Therefore, policies that are oriented toward the protection of fish resources and their ecosystems are urgently needed. The alternative is to provide scientific information, especially relating to local specifics (ecology, economy, and culture). In this regard, local specific components are the primary factors for success in integrated management for seagrass conservation and restoration purposes (de la Torre-Castro 2006; Newmaster et al. 2011).

Furthermore, the objective of seagrass conservation or management is the preservation of fish resources and their ecosystems. In this case, the indicators of fish species diversity that are considered can include fish abundance, population, fish size, and the number and diversity of fish species in seagrass areas, such as marine protected areas (Pregiwati et al. 2015; Yuliana et al. 2019). Scientific facts support the contention that seagrass beds are very important for fishery production and play an essential role in the productivity and biodiversity of coral reefs and other ecosystems in coastal waters (Unsworth and Cullen 2010). However, research efforts to inform policy and practice in this regard are still minimal. From 1,122 articles on seagrass published from 1973 to 2016 in the Asian region (including China), $77 \%$ is high and thus inappropriate, and only $23 \%$ are about science (Fortes 2018). However, there has been little research related to seagrass fisheries resources, fish stocks, or fish communities, particularly to support conservation or management policies at the local and regional scales, such as at the study site. Therefore, this research was conducted to obtain scientific information on the diversity of fish species associated with seagrass. The aim was to provide detailed scientific knowledge as a basis for seagrass conservation efforts at the local scale. The results of this research can serve as a source of information for seagrass conservation policies in the study location, not only for the fisheries sector but also for the development of seagrass beds as natural tourism spots.

\section{MATERIALS AND METHODS}

\section{Site location}

The study was conducted from April to August 2020 at seven locations (Figure 1) in Lombok Island, West Nusa Tenggara Province, Indonesia, i.e. East Lombok District (Gili Kere, Tanjung Luar, Lungkak, and Poton Bakau) and Central Lombok District (Kute, Gerupuk, and Awang). The seagrass species reported at the locations in Central Lombok are as follows: Kute Bay (11 species), Grupuk Bay (10 species) (Kiswara and Winardi, 1994), and Teluk Awang (seven species) (Sari et al. 2020). Meanwhile, nine seagrass species have been reported from the four sampling locations in East Lombok (Syukur et al. 2017). In terms of the environmental conditions around the seagrass areas, some sites — such as Lungkak, Poton Bakau, and Awangwere close to the mangrove ecosystem.

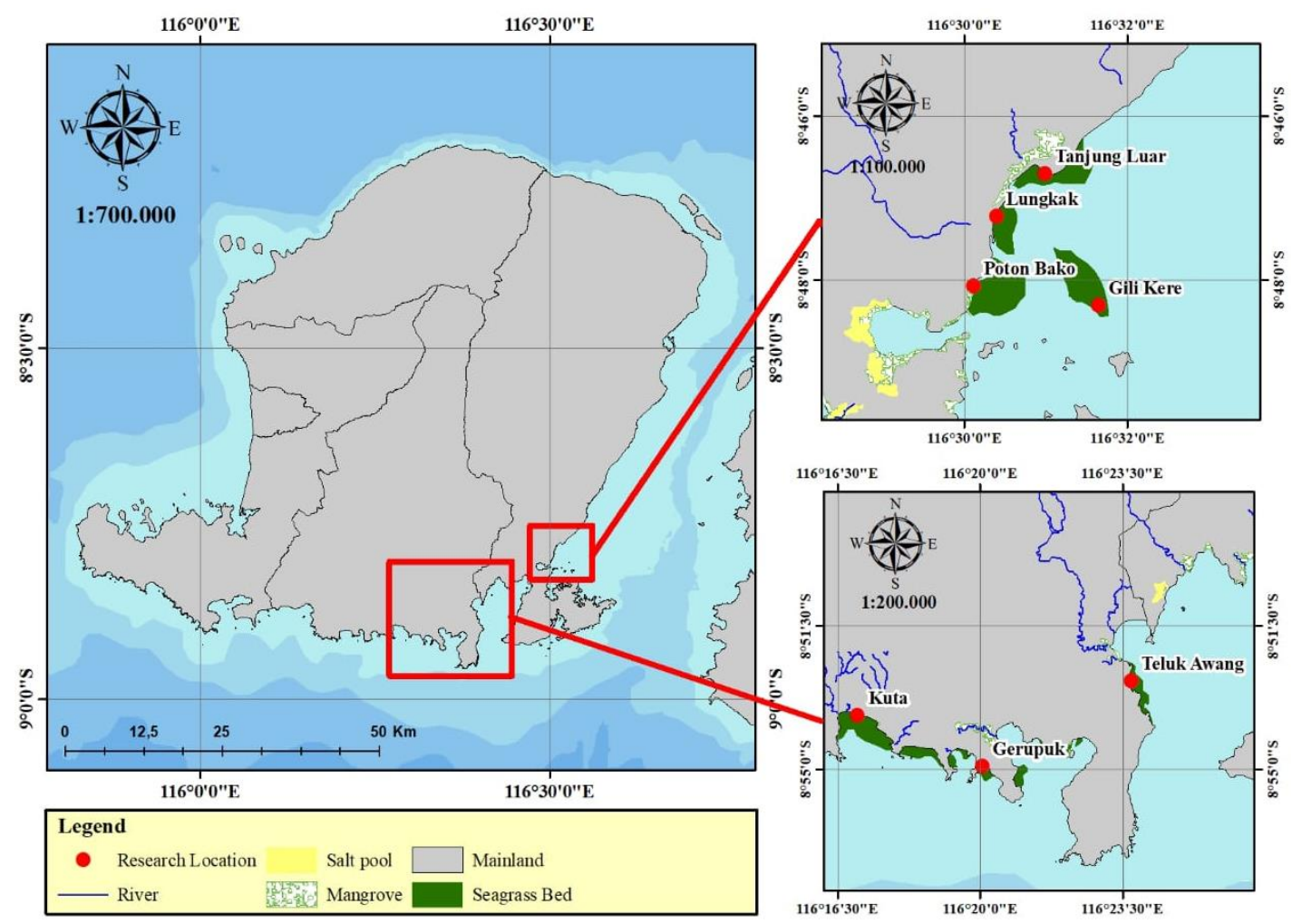

Figure 1. A map of Lombok Island, Indonesia, showing the seven research locations 
Most of the mangrove vegetation along the coast around the research locations is the result of replanting efforts in the early 1990's (Idrus et al. 2019). While the seagrass area at Tanjung Luar is adjacent to the Fish Landing Site, the seagrass sites in Gili Kere, Gerupuk, and Kute are adjacent to coral reef ecosystems, and the latter three seagrass locations have become nature tourism destinations on the southern coast of Lombok Island (Syukur et al. 2020).

\section{Data collection and analysis}

Primary data was collected through surveys and observation at the seven predetermined locations. The data on fish species at each location was collected using fishing gear belonging to the fishers who generally catch fish in the seagrass area. Furthermore, data collection was carried out by the research team, assisted by the fishermen. The fishing gear used was a kind of mini-trawl. The specifications were as follows: net length $80 \mathrm{~m}$ with $1.25^{\prime \prime}, 1 ”, 0.75^{\prime \prime}$, and 0.625 " mesh-size, and 0.5 " mesh at the cod end. The nets were towed by fishing boats at an average speed of $5 \mathrm{~m} /$ minute, with each tow lasting around two hours. Data was collected every month, during the full moon phase (days 14-16 of the lunar phase) from April to August 2019. The fish caught were placed in a container that had been provided.

The fish caught in each sampling tow were grouped and separated according to family and species. The identification of the fish species employed a standard identification reference (Tsukamoto et al. 1997). The data collected was tabulated and analyzed using descriptive statistics. The diversity and composition of the fish community were evaluated using three indices: the Shannon-Waiver diversity index (H ') (Ludwig and Reynolds, 1988), the Simpson evenness index (E), and the Morisita distribution index of species richness (D). Furthermore, a cluster analysis was performed based on the ecological index values (H ', E, and D). All statistical analyses were performed in IBM SPSS Statistics 25.

\section{RESULTS AND DISCUSSION}

\section{Composition of fish in the study area}

The results reveal that 20,352 individual fish (specimens) were identified as belonging to 38 fish families and 104 species (Table 1). Meanwhile, in this study, 16 fish species contributed an above-average number of individuals (more than 192 specimens) to the total sample; they include Archamia goni (19.045\%), Leiognathus equulus (11.100\%), Leiognahus bindus (8.658\%), Sardinella gibbosa (6.761\%), Ambassis buruensis (4.756\%), Scomberoides lysan (2.457\%), Leiognathus splendens (2.241\%), Sillago macrolepis (2.069\%), Apogonichthys ocellatus (2.034\%), Acreichthys tomentosus (2.010\%), Sillago sihama (1.911\%), Leiognathus oblongus (1.695\%), Gazza rhombea (1.322\%), Leiognathus daura (1.125\%), Caranx ignobilis (1.110\%), and Plectorhinchus flavomaculatus $(1.037 \%)$. However, $84 \%$ of the species had below-average values. Furthermore, in the category of species with the number of individuals below the average, 20 species had number of individuals between one and 10, and the fish species with the lowest number of individuals were Gerres erythrourus from the family Gerreidae and Abudefduf sexfasciatus from the family Pomacentridae. Meanwhile, it was found that seven of the 38 families' contribution was above the average of the total number of individuals/families (more than 536): Leiognathidae (27.78\%), Apogonidae (21.41\%), Clupeidae (11.61\%), Carangidae $(8.03 \%)$, Channidae $(4.75 \%)$, Sillaginidae (4.57\%), and Mullidae (2.97\%). Meanwhile, the species composition by fish family (Figure 2) showed that Leiognathidae was the most speciose family, with $10.377 \%$ of species, followed by Carangidae and Tetraodontidae (both contributing 7.547\%), Pomacentridae (6.604\%), and Apogonidae (5.660\%). Therefore, the existence of these seven families is very important in the structure of the fish community in the study location. However, the presence of other families contributes to the species' richness value of the fish communities associated with seagrass in the study location.

Other studies on the number of fish families found in seagrass beds recorded 35 families in the Jordanian coast (Khalaf et al. 2012), 35 families in Ban Pak Klong, Thailand (Phinrub et al. 2014), 41 families in Gazi Bay, Kenya (Musembi et al. 2019), 26 families in Karang Congkak Island, Kepulauan Seribu National Park, Indonesia (Simanjuntak et al. 2020), 24 families in Jervis Bay Marine Park, New South Wales, Australia (Kiggins et al. 2019), 44 families in the seagrass ecosystem of Minicoy Atoll, Lakshadweep, India (Prabhakaran et al. 2013), and 38 families in the inner Ambon Bay, eastern Indonesia (Ambo-Rappe et al. 2013). Furthermore, at twenty-two seagrass beds, there were differences in the number of fish families (Ambo-Rappe 2020). Thus, different locations of seagrass beds, including the study locations, possess different attractions for the fish. This can be influenced by habitat characteristics or habitat structure variability (Bijoy et al. 2013; Vieira et al. 2020), whether the habitat's adjacent to seagrass (mangroves, coral reefs, and other habitats), fragmentation of the seagrass habitat (Hyndes et al. 2018), and the diversity of the seagrass species' morphology (Ambo-Rappe et al. 2013). Furthermore, the existence of fish species in seagrass is useful for assessing the level of species diversity (Short et al. 2007).

The presence of a dominant fish species is another parameter that explains the difference in the composition of fish communities between locations. For instance, in the Quirimba Archipelago, Northern Mozambique, the dominant fish species were Siganus sutor, Leptoscarus vaigiensis, Lethrinus variegatus, Lethrinus lentjan, and Gerres oyena (Gell and Whittington 2002), while in Pak Klong Ban, Thailand, they were Sillago sihama, Leiognathus jonesi, and Gerres erythrourus (Phinrub et al. 2014). With respect to some other sites in Indonesia, at Muara Binuangeun, Lebak Banten, the dominant species were Moolgarda sp and Istiblennius edentulus (Kholis et al. 2017), while Spratelloides gracilis, Stenatherina panatela, Siganus canaliculatus, Gerresoyena sp., and Siganus spinus were the dominant species in the seagrass 
beds of Karang Congkak Island, Kepulauan Seribu National Park, Indonesia (Simanjuntak et al. 2020). In Youtefa Bay, Jayapura, Papua, the dominant species were Scolopsis lineata, Apogon ceramensis, Parupeneus barberinus, Aeliscus strigatus, Siganus fuscescens, and Siganus canaliculatus (Tebaiy et al. 2017). Fish species that gather on seagrass with dominant indicators of species richness and species constitute the main value of seagrass as a fish habitat (Nordlund et al. 2018). Therefore, in this study, the species richness and dominant fish species are important information that provides a scientific basis for protecting or conserving seagrass.

Table 1. The total number and species composition of the sampled fish associated with seagrass at the seven study locations.

\begin{tabular}{|c|c|c|c|}
\hline Family & Species & 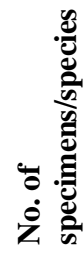 & 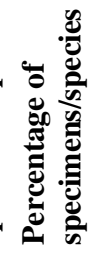 \\
\hline \multirow[t]{5}{*}{ Apogonidae } & Apogonichthys ocellatus & 414 & 2.03 \\
\hline & Archamia goni & 3876 & 19.04 \\
\hline & Archamia zosterophora & 14 & 0.07 \\
\hline & Cheilodipterus macrodon & 51 & 0.25 \\
\hline & Foa brachygramma & 3 & 0.01 \\
\hline \multirow[t]{2}{*}{ Atherinidae } & Atherinomorus duodecimalis & 2 & 0.01 \\
\hline & Atherinomorus lacunosus & 30 & 0.15 \\
\hline \multirow[t]{3}{*}{ Blenniidae } & Alticus saliens & 72 & 0.35 \\
\hline & Andamia tetradactylus & 5 & 0.02 \\
\hline & Petroscirtes variabilis & 89 & 0.44 \\
\hline Bothidae & Bothus pantherinus & 30 & 0.15 \\
\hline Channidae & Ambassis buruensis & 968 & 4.76 \\
\hline \multirow[t]{8}{*}{ Carangidae } & Atule mate & 153 & 0.75 \\
\hline & Caranx ignobilis & 226 & 1.11 \\
\hline & Caranx melampygus & 108 & 0.53 \\
\hline & Caranx sexfasciatus & 393 & 1.93 \\
\hline & Scomberoides tala & 40 & 0.20 \\
\hline & Selar crumenophthalmus & 142 & 0.70 \\
\hline & Scomberoides lysan & 500 & 2.46 \\
\hline & Trachinotus blochii & 73 & 0.36 \\
\hline \multirow[t]{2}{*}{ Clupeidae } & Sardinella gibbosa & 1376 & 6.76 \\
\hline & Sardinella lemuru & 987 & 4.85 \\
\hline \multirow[t]{2}{*}{ Cynoglossidae } & Paraplagusia bilineata & 28 & 0.14 \\
\hline & Paraplagusia blochi & 29 & 0.14 \\
\hline Diodontidae & Diodon liturosus & 6 & 0.03 \\
\hline \multirow[t]{3}{*}{ Engraulidae } & Stolephorus commersonii & 54 & 0.27 \\
\hline & Stolephorus indicus & 268 & 1.32 \\
\hline & Thryssa setirostris & 9 & 0.04 \\
\hline Ephippidae & Platax boersii & 20 & 0.10 \\
\hline Fistulariidae & Fistularia commersonii & 38 & 0.19 \\
\hline \multirow[t]{4}{*}{ Gerreidae } & Gerres abbreviatus & 53 & 0.26 \\
\hline & Gerres erythrourus & 1 & 0.00 \\
\hline & Gerres filamentosus & 370 & 1.82 \\
\hline & Gerres oyena & 44 & 0.22 \\
\hline \multirow[t]{2}{*}{ Haemulidae } & Plectorhinchus celebicus & 54 & 0.27 \\
\hline & Plectorhinchus flavomaculatus & 211 & 1.04 \\
\hline Hemiramphidae & Hemiramphus far & 144 & 0.71 \\
\hline \multirow[t]{2}{*}{ Labridae } & Halichoeres papilionaceus & 2 & 0.01 \\
\hline & Thalassoma hardwicke & 3 & 0.01 \\
\hline
\end{tabular}

\begin{tabular}{|c|c|c|c|}
\hline \multirow[t]{12}{*}{ Leiognathidae } & Ambassis urotaenia & 27 & 0.13 \\
\hline & Gazza achlamys & 15 & 0.07 \\
\hline & Gazza minuta & 92 & 0.45 \\
\hline & Cynoglossus puncticeps & 18 & 0.09 \\
\hline & Gazza rhombea & 269 & 1.32 \\
\hline & Leiognathus daura & 229 & 1.13 \\
\hline & Leiognathus equulus & 2259 & 11.10 \\
\hline & Leiognathus bindus & 1762 & 8.66 \\
\hline & Leiognathus rapsoni & 56 & 0.28 \\
\hline & Leiognathus splendens & 456 & 2.24 \\
\hline & Leiognathus oblongus & 345 & 1.70 \\
\hline & Secutor interruptus & 127 & 0.62 \\
\hline \multirow[t]{2}{*}{ Lethrinidae } & Gymnocranius elongatus & 64 & 0.31 \\
\hline & Lethrinus variegatus & 24 & 0.12 \\
\hline \multirow[t]{4}{*}{ Lutjanidae } & Lutjanus argentimaculatus & 108 & 0.53 \\
\hline & Lutjanus boutton & 103 & 0.51 \\
\hline & Lutjanus erythropterus & 64 & 0.31 \\
\hline & Lutjanus & 91 & 0.45 \\
\hline Mugilidae & Moolgarda delicates & 109 & 0.54 \\
\hline \multirow[t]{4}{*}{ Mullidae } & Pempheris oualensis & 22 & 0.11 \\
\hline & Upeneus sulphureus & 84 & 0.41 \\
\hline & Upeneus tragula & 24 & 0.12 \\
\hline & Upeneus vittatus & 476 & 2.34 \\
\hline \multirow[t]{2}{*}{ Monacanthidae } & Acreichthys tomentosus & 409 & 2.01 \\
\hline & Acreichthys sp. & 68 & 0.33 \\
\hline Plotosidae & Plotosus lineatus & 3 & 0.01 \\
\hline \multirow[t]{2}{*}{ Polynemidae } & Filimanus xanthone & 162 & 0.80 \\
\hline & Polynemus plebeius & 9 & 0.04 \\
\hline \multirow[t]{7}{*}{ Pomacentridae } & Abudefduf notatus & 16 & 0.08 \\
\hline & Abudefduf vaigiensis & 11 & 0.05 \\
\hline & Abudefduf sexfasciatus & 1 & 0.00 \\
\hline & Abudefduf septemfasciatus & 6 & 0.03 \\
\hline & Amphiprion frenatus & 11 & 0.05 \\
\hline & Neopomacentrus azysron & 55 & 0.27 \\
\hline & Pomacentrus lepidogenys & 5 & 0.02 \\
\hline \multirow[t]{2}{*}{ Scaridae } & Calotomus spinidens & 24 & 0.12 \\
\hline & Leptoscarus vaigiensis & 33 & 0.16 \\
\hline \multirow[t]{3}{*}{ Scianidae } & Johnius amblycephalus & 7 & 0.03 \\
\hline & Johnius borneensis & 2 & 0.01 \\
\hline & Johnius macropterus & 6 & 0.03 \\
\hline Scorpaenidae & Ablabys taenianotus & 4 & 0.02 \\
\hline Serranidae & Epinephelus bontoides & 66 & 0.32 \\
\hline \multirow[t]{3}{*}{ Siganidae } & Siganus argenteus & 12 & 0.06 \\
\hline & Siganus canaliculatus & 62 & 0.30 \\
\hline & Siganus guttatus & 42 & 0.21 \\
\hline \multirow[t]{3}{*}{ Sillaginidae } & Sillago chondropus & 121 & 0.59 \\
\hline & Sillago sihama & 389 & 1.91 \\
\hline & Sillago macrolepis & 421 & 2.07 \\
\hline Soleidae & Cynoglossus lingua & 22 & 0.11 \\
\hline Sphyraenidae & Sphyraena barracuda & 25 & 0.12 \\
\hline \multirow[t]{2}{*}{ Syngnathidae } & Syngnathoides biaculeatus & 2 & 0.01 \\
\hline & Synodus dermatogenys & 4 & 0.02 \\
\hline \multirow[t]{3}{*}{ Synodontidae } & Saurida gracilis & 2 & 0.01 \\
\hline & Saurida nebulosa & 47 & 0.23 \\
\hline & Sphyraena flavicauda & 46 & 0.23 \\
\hline \multirow[t]{8}{*}{ Tetraodontidae } & Arothron immaculatus & 179 & 0.88 \\
\hline & Arothron manilensis & 118 & 0.58 \\
\hline & Canthigaster compressa & 51 & 0.25 \\
\hline & Chelonodon patoca & 51 & 0.25 \\
\hline & Lagocephalus gloveri & 8 & 0.04 \\
\hline & Lagocephalus ivheeleri & 12 & 0.06 \\
\hline & Lagocephalus lunaris & 3 & 0.01 \\
\hline & Takifugu radiatus & 2 & 0.01 \\
\hline Triacanthidae & Triacanthus nieuhofi & 36 & 0.18 \\
\hline Trichiuridae & Trichiurus lepturus & 89 & 0.44 \\
\hline & Total & 20352 & 100 \\
\hline
\end{tabular}




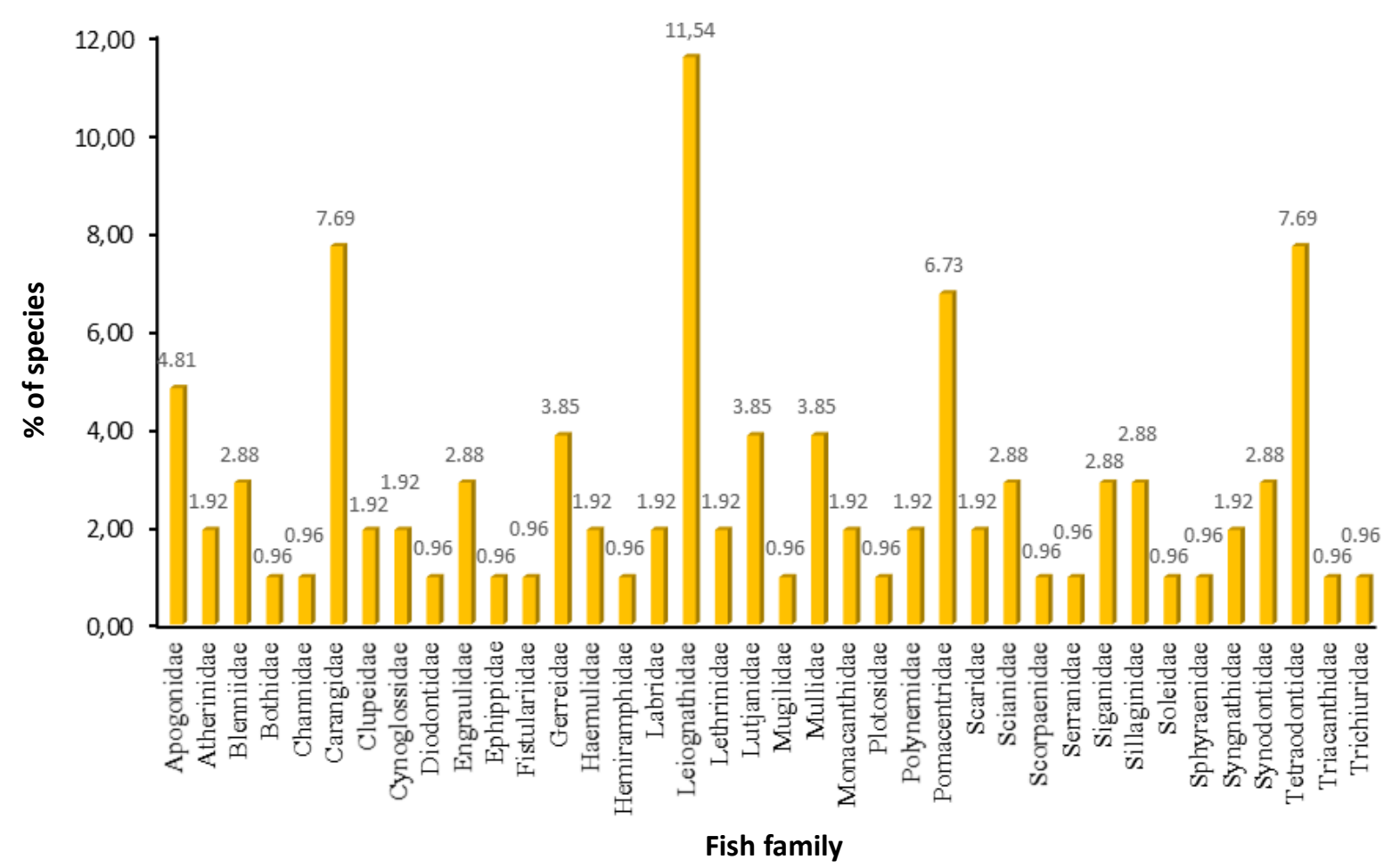

Figure 2. Fish community composition by family based on the number of species present in the seven study locations

\section{Ecological index of fish species associated with seagrass in the seven study sites}

The results of the analysis of the diversity index ( $\mathrm{H}$ '), evenness index (E), and species richness index (D) at the seven sampling locations are shown in Figure 3. The results of this study indicate that Tanjung Luar is the location with the highest H ', E, and D values, and Gerupak is the location with the lowest ecological index values for $\mathrm{H}$ ', $\mathrm{E}$, and D. Meanwhile, the diversity index value at all seagrass locations was between 2.40 and 2.80, with an average value of 2.61. Meanwhile, the species richness index values were between 2.14 and 8.47, with an average of 7.74, and the evenness index ranged from 0.57-0.69, with an average value of 0.62 . In this case, the value of $H^{\prime}$ can describe the structure of the fish community at the seven sampling locations. In addition, it can explain the distribution of species based on the number of individuals. However, the value of $\mathrm{E}$, which is below one, indicates that no fish species is very dominant at the seven sampling locations. Ecological indices, in addition to those described above. The next assessment was based on month (Table 2). The results of the analysis show that the average $\mathrm{H}$ 'value at the seven sampling locations was $2.35 \pm 0.24$ $2.80 \pm 0.19$, the average $E$ value was $0.59 \pm 0.08-0.78 \pm$ 0.10 , and the average $\mathrm{D}$ value was $6.30 \pm 0.17-8.51 \pm 0.35$. Meanwhile, the highest $H$ 'value was 2.99 in June in Kute, and the lowest was 2.21 in April in Gili Kere. The highest E value was 0.89 in June, and the lowest was 0.49 in April in Gili Kere. Finally, the highest D value was 8.80 in June in Tanjung Luar, and the lowest was 6.04 in April in Gerupuk. Because of this, the ecological index value of fish species found in the study location can provide environmental evidence that the presence of seagrass is needed by marine organisms to survive, but that fish density in seagrass is often dominated by juvenile fish groups (Dorenbosch et al. 2005; Hylkema et al. 2015). Moreover, it can explain the vital role of seagrass to fish, which includes providing food, rearing, and protection from predators, and especially fish biodiversity (Jackson et al. 2001; Heck et al. 2003; Bertelli and Unsworth 2014; Prasetya and Purwanti 2017; Hidayati and Suparmoko 2018).

The results of the one-way ANOVA analysis of the ecological index values (H ', E, and D) are presented in Table 2. $\mathrm{H}$ ' and $\mathrm{E}$ show no significant differences, with an

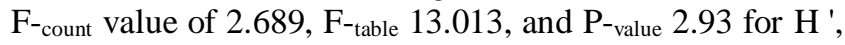
and $\mathrm{F}_{\text {-count }}$ 2.758, $\mathrm{F}_{\text {-table }}$ 5.012, and $\mathrm{P}_{\text {-value }} 0.004$ for $\mathrm{E}$. Meanwhile, the value of $\mathrm{D}$ shows that there is a significant difference, with $\mathrm{F}_{\text {count }} 2.758, \mathrm{~F}_{\text {table }}$ 0.582, and P-value 0.677 (Table 3). This explains that the seven seagrass beds have extremely different species and individuals that are evenly distributed or not. The significant difference in the values of $\mathrm{D}$ can be explained through the results of the analysis cluster (Figure 4), where Awang and Lungkak are in one group and have similar characteristics, namely that they are situated close to river estuaries and mangrove ecosystems. Furthermore, Gili Kere and Poton Bakau are in one group because they are in close proximity. Other locations, such as Tanjung Luar, have similarities with Gili Kere and Poton Bakau, Kute has similarities with Lungkak and Awang, and only Gerupk does not belong to the first and second stage grouping. Furthermore, the composition of the fish species at the seven sampling locations consisted $94.37 \%$ of the commercial fish or the target fish families caught by fishermen. In this case, more than $20 \%$ of the commercial fish species experience a shift in habitat use between 
ecosystems adjacent to seagrass (Honda et al. 2013). commercial fish species has contributed to the differences Therefore, the presence of other ecosystems and in fish species richness, such as in the study sites.

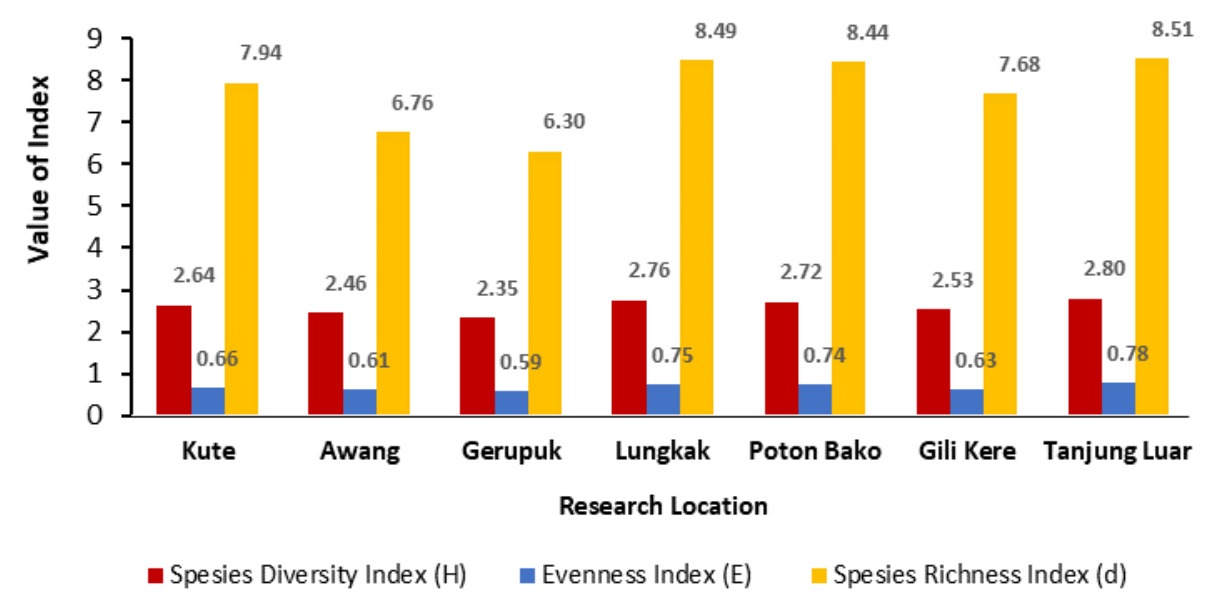

Figure 3. Diversity index, evenness index, and species richness index at the seven survey locations in the study area

Table 2. Ecological index values for seagrass-associated fish species by month at the seven study locations

\begin{tabular}{|c|c|c|c|c|c|c|c|}
\hline \multirow{2}{*}{ Location } & \multirow{2}{*}{ Index } & \multicolumn{6}{|c|}{ Month } \\
\hline & & April & May & June & July & August & Mean \pm SD \\
\hline \multirow{3}{*}{ Kute } & Species Diversity Index (H ') & 2.31 & 2.52 & 2.99 & 2.64 & 2.76 & $2.64 \pm 0.26$ \\
\hline & Evenness Index (E) & 0.57 & 0.65 & 0.72 & 0.67 & 0.69 & $0.66 \pm 0.06$ \\
\hline & Species Richness Index (D) & 7.56 & 7.79 & 8.2 & 8.04 & 8.11 & $7.94 \pm 0.26$ \\
\hline \multirow{4}{*}{ Awang } & Species Diversity Index ( $\left.\mathrm{H}^{\prime}\right)$ & 2.11 & 2.32 & 2.71 & 2.46 & 2.68 & $2.46 \pm 0.25$ \\
\hline & Evenness Index (E) & 0.51 & 0.56 & 0.67 & 0.62 & 0.68 & $0.61 \pm 0.07$ \\
\hline & Species Richness Index (D) & 6.42 & 6.62 & 7.09 & 6.78 & 6.88 & $6.76 \pm 0.25$ \\
\hline & Species Diversity Index ( $\left.\mathrm{H}^{\prime}\right)$ & 2.09 & 2.18 & 2.64 & 2.28 & 2.56 & $2.35 \pm 0.24$ \\
\hline \multirow[t]{2}{*}{ Gerupuk } & Evenness Index (E) & 0.5 & 0.53 & 0.69 & 0.56 & 0.66 & $0.59 \pm 0.08$ \\
\hline & Species Richness Index (D) & 6.04 & 6.26 & 6.48 & 6.31 & 6.41 & $6.30 \pm 0.17$ \\
\hline \multirow{3}{*}{ Lungkak } & Species Diversity Index ( $\left.\mathrm{H}^{\prime}\right)$ & 2.46 & 2.65 & 2.99 & 2.73 & 2.97 & $2.76 \pm 0.22$ \\
\hline & Evenness Index (E) & 0.69 & 0.71 & 0.82 & 0.74 & 0.81 & $0.75 \pm 0.06$ \\
\hline & Species Richness Index (D) & 8.14 & 8.23 & 8.91 & 8.41 & 8.76 & $8.44 \pm 0.37$ \\
\hline \multirow{3}{*}{ Poton Bako } & Species Diversity Index ( $\left.\mathrm{H}^{\prime}\right)$ & 2.38 & 2.43 & 2.97 & 2.87 & 2.93 & $2.72 \pm 0.29$ \\
\hline & Evenness Index (E) & 0.65 & 0.67 & 0.81 & 0.75 & 0.81 & $0.74 \pm 0.08$ \\
\hline & Species Richness Index (D) & 7.93 & 8.21 & 8.88 & 8.49 & 8.67 & $8.49 \pm 0.33$ \\
\hline \multirow{3}{*}{ Gili Kere } & Species Diversity Index ( $\left.\mathrm{H}^{\prime}\right)$ & 2.12 & 2.21 & 3.01 & 2.59 & 2.73 & $2.53 \pm 0.37$ \\
\hline & Evenness Index (E) & 0.49 & 0.59 & 0.82 & 0.59 & 0.64 & $0.63 \pm 0.12$ \\
\hline & Species Richness Index (D) & 7.21 & 7.41 & 8.11 & 7.76 & 7.89 & $7.68 \pm 0.36$ \\
\hline \multirow{3}{*}{ Tanjung Luar } & Species Diversity Index ( $\left.\mathrm{H}^{\prime}\right)$ & 2.51 & 2.71 & 2.98 & 2.93 & 2.87 & $2.80 \pm 0.19$ \\
\hline & Evenness Index (E) & 0.65 & 0.71 & 0.89 & 0.81 & 0.82 & $0.78 \pm 0.10$ \\
\hline & Species Richness Index (D) & 8.04 & 8.21 & 8.80 & 8.72 & 8.76 & $8.51 \pm 0.35$ \\
\hline
\end{tabular}

Table 3. The results of the one-way ANOVA analysis of the ecological indices for seagrass-associated fish at the seven study locations $(\dot{\alpha}=0,05)$

\begin{tabular}{llccc}
\hline One-way ANOVA & Source of variation & Diversity index $\left(\mathbf{H}^{\prime}\right)$ & Evenness index(E) & Richness index $(\mathbf{D})$ \\
\hline \multirow{2}{*}{ SS } & Between Groups & 1.778 & 0.157 & 2.194 \\
& Within Groups & 1.025 & 0.196 & 23.532 \\
df & Between Groups & 4 & 4 & 4 \\
& Within Groups & 30 & 25 & 25 \\
MS & Between Groups & 0.444 & 0.039 & 0.548 \\
F crit & Within Groups & 0.034 & 0.007 & 0.941 \\
F table & & 2.689 & 2.758 & 2.758 \\
P-value & & 13.013 & 5.012 & 0.582 \\
\hline
\end{tabular}




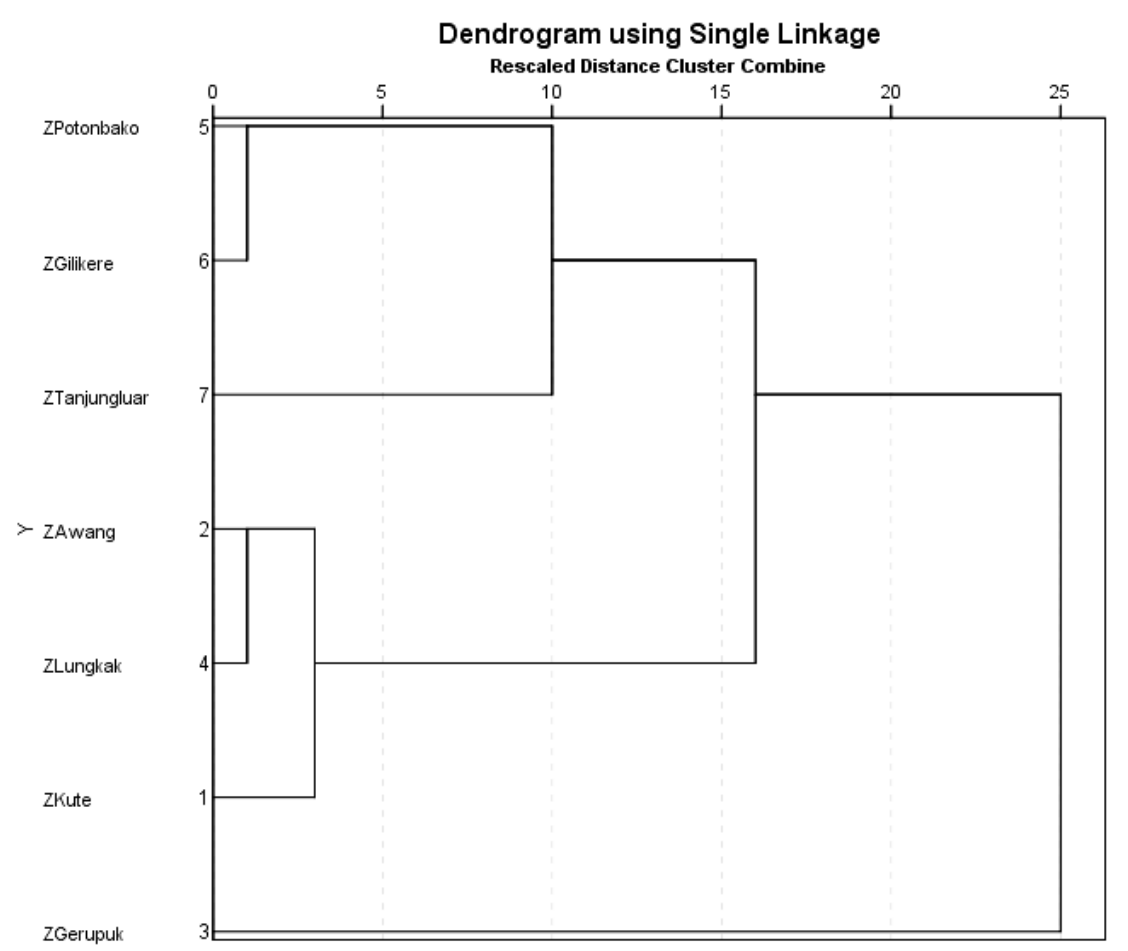

Figure 4. Cluster analysis of the Euclidean distance between seagrass-associated fish communities at the seven study sites

\section{Seagrass conservation}

Several research results have proven the importance of intertidal areas, such as mangroves, seagrass beds, and coral reefs, as fish habitats (Unsworth et al. 2009; Honda et al. 2013; Aller et al. 2014; Nagelkerken et al. 2014; Moussa 2018; Moussa et al. 2020). In particular, seagrass beds have contributed to supporting global fisheries' production and local-scale fisheries' sustainability (Nordlund et al. 2018; Unsworth et al. 2019a; Ambo-Rappe 2020). The results of this study indicate the potential to support small-scale fisheries in the study locations. First is the level of distribution of fish species at the seven sampling locations (Table 4); second, $25.96 \%$ of fish species can be found at all locations, and only $7.69 \%$ are found at one location; third, the richness of fish species at each location is above the average value, i.e., 14.42 out of 104 species at all locations, and the highest number of species is found in Gili Kere (73.08\%) and the lowest is in Awang (48.08\%) (Figure 5); fourth, 94.73\% of fish families are fish groups that are the target catch of smallscale fishermen, and among the families that are not, only 5. Moreover, 26\% are from Apogonidae and Cynoglossidae (Table 1). Therefore, the existence of seagrass beds in the study location is very important for the economic sustainability of small-scale fishermen. Meanwhile, the richness of fish species associated with seagrass in the seven sampling locations is a source of the biodiversity of fish resources, which must be protected.

Furthermore, the results of this study can explain the value of the ecological indices $\mathrm{H}$ ', E, and D quantitatively (Figure 3 and Table 2) as indicators of the role of seagrass ecological services in providing habitat, food, and shelter from predators. Therefore, the results of this study can become a reference for the design of seagrass conservation plans or seagrass management, worked into an integrated and sustainable management system at the study site. Moreover, the results can become the basis for monitoring and evaluating the changes caused by disturbances or threats, such as species overexploitation, habitat destruction, and other anthropogenic activities as well as climate change. This is very important given the disturbance to biodiversity, especially fish resources, despite conservation efforts, where the loss of biodiversity continues at a regional or global scale in various ecosystems (Mouillot et al. 2013; Villéger et al. 2010). If environmental management is neglected, such as in the study location, it can cause a reduction in the value of biodiversity, particularly fish resources, which will affect the sustainability of ecological processes and the provision of ecosystem services.

The current problem that cannot be resolved is the degradation of seagrass habitats, which can reduce the supply of fish produced by small-scale fishermen. Furthermore, the status of seagrass conditions determines the livelihoods of small-scale fishermen (Cullen-Unsworth et al. 2014; de la Torre-Castro et al. 2014). Therefore, efforts to maintain the condition of the seagrass can be done through conservation. This is very important, as seen by how seagrass conservation through restoration in southern Australia has increased the populations of 15 commercial fish species (Blandon and $\mathrm{Zu}$ Ermgassen 2014). Another study explains that the economic value of seagrass beds is dominated by the species Cymodocea nodosa, which greatly determines the sustainability of local 
fisheries in East Atlantic oceanic islands, especially for fishing and breeding (Tuya et al. 2014). According to the results of this study, $94.73 \%$ of the fishermen's target fish group contributed to supporting the sustainability of smallscale fisheries' production. Another extremely important aspect of the results is the value of the ecological indices, where at two sampling locations, the $\mathrm{H}$ ' values of 2.53 in Gili Kere and 2.76 in Lungak were higher than in 2017, when the values were 2.448 in Gili Kere and 2.60 in Lungkak (Syukur et al. 2017). However, in two other locations Poton Bakau and Tanjung Luar (Kampung Baru), the values of $\mathrm{H}^{\prime}$ were lower than in 2017. Therefore, the study of seagrass provisioning services, particularly for fish resources, is produced as scientific information for the management or conservation of local-scale seagrass at the study location.

In connection with the seagrass-associated fish species in the study location, maintaining fish habitats, such as preventing or restraining the damage rate, is crucial. Furthermore, seagrass protection efforts can prevent the degradation or loss of seagrass ecosystem services in the ecosystems of coastal waters, especially for protecting marine biodiversity. Moreover, the damage to seagrass can have negative implications by decreasing the productivity of marine resources, disrupting trophic interactions, and reducing stability in the natural ecosystems in the marine environment (Duffy 2006; Duffy et al. 2015; Best and Stachowicz 2012). In addition, the loss of seagrass vegetation can have a direct effect on fish that need seagrass as a habitat (Patro et al. 2017; Mishra et al. 2019).
Therefore, practical initiatives are needed in the conceptualization of pilots to conserve exemplary seagrass beds. In this case, the conservation of seagrass beds can be realized through the participation of fishing communities, especially small-scale fishermen.

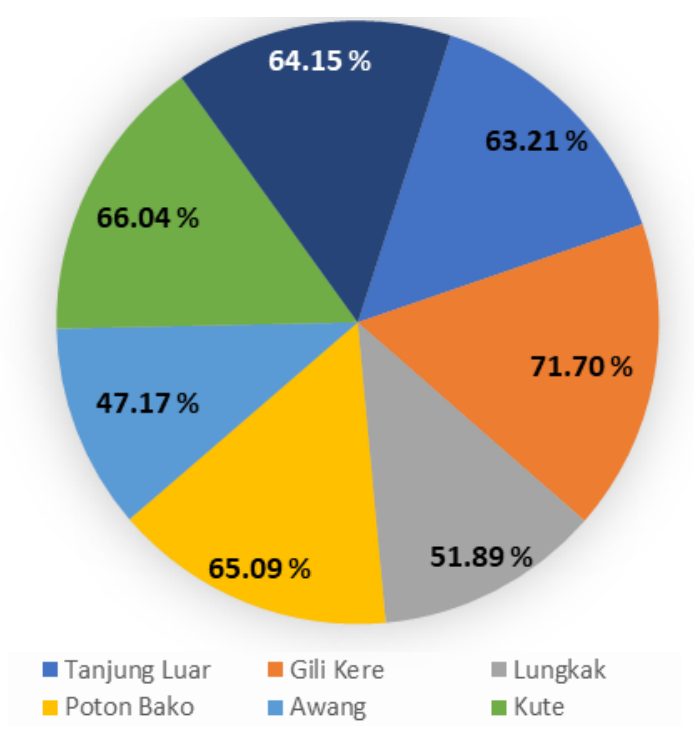

Figure 5. The percentage of all seagrass-associated fish species identified in this study found at each of the seven locations

Table 4. Spatial distribution of the seagrass-associated fish species identified in this study

\begin{tabular}{|c|c|c|}
\hline $\begin{array}{l}\text { Spatial } \\
\text { distribution }\end{array}$ & Species present & $\begin{array}{c}\text { Number } \\
\text { of species }\end{array}$ \\
\hline All Locations & $\begin{array}{l}\text { Acreichthys tomentosus, Ambassis buruensis, Archamia goni, Canthigaster compressa, Caranx ignobilis, } \\
\text { Caranx melampygus, Caranx sexfasciatus, Chelonodon patoca, Calotomus spinidens, Epinephelus } \\
\text { bontoides, Fistularia commersonii, Gazza minuta, Gazza rhombea, Leiognathus bindus, Leiognathus } \\
\text { daura, Leiognathus equulus, Leiognathus rapsoni, Lutjanus argentimaculatus, Lutjanus boutton, } \\
\text { Lutjanus erythropterus, Moolgarda delicates, Sardinella gibbosa, Saurida nebulosa, Secutor interruptus, } \\
\text { Siganus canaliculatus, Sillago sihama, Stolephorus indicus, Upeneus vittatus }\end{array}$ & 27 \\
\hline Six locations & $\begin{array}{l}\text { Abudefduf vaigiensis, Ambassis urotaenia, Gerres filamentosus, Paraplagusia blochi, Scomberoides } \\
\text { lysan, Sillago macrolepis, Stolephorus commersonii, Bothus pantherinus, Sardinella lemuru }\end{array}$ & 9 \\
\hline Five locations & $\begin{array}{l}\text { Alticus saliens, Arothron immaculatus, Arothron manilensis, Atule mate, Gazza achlamys, Leiognathus } \\
\text { oblongus, Platax boersii, Plectorhinchus celebicus, Plectorhinchus flavomaculatus, Selar } \\
\text { crumenophthalmus }\end{array}$ & 10 \\
\hline $\begin{array}{l}\text { Four } \\
\text { locations }\end{array}$ & $\begin{array}{l}\text { Abudefduf notatus, Cheilodipterus macrodon, Hemiramphus far, Leiognathus splendens, Siganus } \\
\text { guttatus, Sphyraena barracuda, Sphyraena flavicauda, Triacanthus nieuhofi, Upeneus sulphureus }\end{array}$ & 9 \\
\hline Three & Abudefduf septemfasciatus, Acreichthys sp., Apogonichthys ocellatus, Archamia zosterophora, & 23 \\
\hline Locations & $\begin{array}{l}\text { Atherinomorus lacunosus, Cynoglossus lingua, Cynoglossus puncticeps, Filimanus xanthone, } \\
\text { Gymnocranius elongatus, Johnius amblycephalus, Johnius macropterus, Lagocephalus ivheeleri, } \\
\text { Lagocephalus lunaris, Leptoscarus vaigiensis, Lethrinus variegatus, Plotosus lineatus, Polynemus } \\
\text { plebeius, Pomacentrus lepidogenys, Sillago chondropus, Thalassoma hardwicke, Trachinotus blochii, } \\
\text { Trichiurus lepturus, Upeneus tragula }\end{array}$ & \\
\hline $\begin{array}{l}\text { Two } \\
\text { Locations }\end{array}$ & $\begin{array}{l}\text { Amphiprion frenatus, Atherinomorus duodecimalis, Diodon liturosus, Pempheris oualensis, Foa } \\
\text { brachygramma, Gerres abbreviatus, Gerres oyena, Halichoeres papilionaceus, Johnius borneensis, } \\
\text { Lagocephalus gloveri, Lutjanus, Paraplagusia bilineata, Petroscirtes variabilis, Saurida gracilis, } \\
\text { Scomberoides tala, Siganus argenteus, Synodus dermatogenys }\end{array}$ & 18 \\
\hline One Location & $\begin{array}{l}\text { Abudefduf sexfasciatus, Andamia tetradactylus, Gerres erythrourus, Neopomacentrus azysron, } \\
\text { Syngnathoides biaculeatus, Takifugu radiatus, Thryssa setirostris, Ablabys taenianotus }\end{array}$ & 8 \\
\hline \multicolumn{2}{|c|}{ Total Number of Species } & 104 \\
\hline
\end{tabular}


In conclusion, the fish communities associated with seagrass in the study sites have two main dimensions in relation to conservation. The first aspect of the diversity of fish species found in the seagrass area in the study location constitutes ecological evidence of the contribution of seagrasses to the sustainability of fish communities. Second, $94.73 \%$ of the fish families targeted by small-scale fishermen contribute to supporting the sustainability of small-scale fisheries' production. It is hoped that these two factors can become the primary considerations in the localscale seagrass management and conservation plan in the study location. Consequently, seagrass conservation efforts at various scales, especially outside protected areas such as the study location and others, are urgently needed to protect and preserve marine biodiversity and economic sustainability for local human communities.

\section{ACKNOWLEDGEMENTS}

The authors are thankful to the Directorate General of Strengthening Research and Development. Directorate of Research and Community Service, Ministry of Research, Technology and Higher Education of Indonesia for providing the funding for carrying out this study, based on decree number: 25/E1/KPT2020, and agreement/contract number: 1734/UN18.L1/PP/2020. AA, AAI, and LZ have conducted all experiments, participated in data analysis and preparation of the manuscript.

\section{REFERENCES}

Aller EA, Gullström M, Maarse FKE, Gren M, Nordlund M, Jiddawi N, Eklöf JS. 2014. Single and joint effects of regional-and local-scale variables on tropical seagrass fish assemblages. Mar Biol 161 (10): 2395-2405. DOI 10.1007/s00227-014-2514-7.

Ambo-Rappe R, Nessa MN, Latuconsina H, Lajus DL. 2013. Relationship between the tropical seagrass bed characteristics and the structure of the associated fish community. Open J Ecol 3(5): 331. DOI 10.4236/oje.2013.35038.

Ambo-Rappe R. (2010). Fish community structure in different seagrass beds of Barrang Lompo Island. Jurnal Ilmu dan Teknologi Kelautan Tropis. 2(2). DOI: 10.29244/jitkt.v2i2.7853

Ambo-Rappe, R. (2020). Seagrass meadows for fisheries in Indonesia: a preliminary study. IOP Conf Ser Earth Environ Sci 564: 012017. DOI: 10.1088/1755-1315/564/1/012017.

Anton A, Baldry K, Coker DJ, Duarte CM. 2020. Drivers of the Low Metabolic Rates of Seagrass Meadows in the Red Sea. Front Mar Sci 7: 69. DOI: 10.3389/fmars.2020.00069.

Bertelli CM, Unsworth RK, 2014. Protecting the hand that feeds us: Seagrass (Zostera marina) serves as commercial juvenile fish habitat. $\begin{array}{lllll}\text { Mar Pollut } & \text { Bull } 83 & \text { (2): 425-429. DOI: }\end{array}$ 10.1016/j.marpolbul.2013.08.011.

Best RJ, Stachowicz JJ. 2012. Trophic cascades in seagrass meadows depend on mesograzer variation in feeding rates, predation susceptibility, and abundance. Mar Ecol Prog Ser 456: 29-42. DOI: 10.3354/meps09678

Bijoy NS, Prabhakaran MP, Pillai NGK, Jayachandran PR. 2013. Species diversity and community structure of ichthyofauna in the seagrass ecosystem of Minicoy Atoll, Lakshadweep, India. Indian J Geo-Mar Sci 42 (3): 349-359.

Blandon A, Zu Ermgassen PS. 2014. Quantitative estimate of commercial fish enhancement by seagrass habitat in southern Australia. Estuar Coast Shelf Sci 141: 1-8. DOI: 10.1016/j.ecss.2014.01.009

Cullen-Unsworth LC, Nordlund LM, Paddock J, Baker S, McKenzie LJ, Unsworth RK. 2014. Seagrass meadows globally as a coupled social- ecological system: Implications for human wellbeing. Mar Pollut Bull 83 (2): 387-397. DOI: 10.1016/j.marpolbul.2013.06.001

de la Torre-Castro M, Di Carlo G, Jiddawi NS. 2014. Seagrass importance for a small-scale fishery in the tropics: The need for seascape management. Mar Pollut Bull 83 (2). 398-407. DOI: 10.1016/j.marpolbul.2014.03.034

de la Torre-Castro M. 2006. Humans and Seagrasses in East Africa: A social-ecological systems approach. Stockholm: Department of Systems Ecology. Stockholm University, Sweden. DOI: 10.1016/j.marpolbul.2013.06.001

Dorenbosch M, Grol MGG, Christianen MJA, Nagelkerken I, Van Der Velde G. 2005. Indo-Pacific seagrass beds and mangroves contribute to fish density and diversity on adjacent coral reefs. Mar Ecol Prog Ser 302: 63-76. DOI: 10.3354/meps302063.

Du J, Xie M, Wang Y, Chen Z, Liu W, Liao J, Chen B. 2019. Connectivity of fish assemblages along the mangrove-seagrass-coral reef continuum in Wenchang. China. Acta Oceanolog Sin. DOI: 10.1007/s13131-019-1490-7.

Duffy JE, Reynolds PL, Boström C, Coyer JA, Cusson M, Donadi S, Fredriksen S. 2015. Biodiversity mediates top-down control in eelgrass ecosystems: a global comparative-experimental approach. Ecol Lett 18 (7): 696-705. DOI: 10.1111/ele.12448.

Duffy JE. 2006. Biodiversity and the functioning of seagrass ecosystems. Mar Ecol Prog Ser 311: 233-250. DOI: 10.3354/meps311233.

Fortes MD. 2018. Seagrass ecosystem conservation in Southeast Asia needs to link science to policy and practice. Ocean Coast Manag 159: 51-56. DOI: 10.1016/j.ocecoaman.2018.01.028.

Gell FR, Whittington, MW. 2002. diversity of fishes in seagrass beds in the Quirimba Archipelago. northern Mozambique. Mar Freshw Res 53 (2): 115-121. DOI: 10.1071/MF01125.

Griffiths LL, Connolly RM, Brown CJ. 2020. Critical gaps in seagrass protection reveal the need to address multiple pressures and cumulative impacts. Ocean Coast Manag 183: 104946. DOI: 10.1016/j.ocecoaman.2019.104946.

Heck Jr KL, Hays G, Orth RJ. 2003. Critical evaluation of the nursery role hypothesis for seagrass meadows. Mar Ecol Prog Ser 253: 123-136.

Henderson CJ, Stevens T, Lee SY, Gilby BL, Schlacher TA, Connolly R.M, Warnken J, Maxwell PS, Olds AD. 2019. Optimising seagrass conservation for ecological functions. Ecosystems 22 (6): 1368-1380. DOI: $10.1007 / \mathrm{s} 10021-019-00343-3$.

Hidayati N, Suparmoko M. 2018. Fish assemblage structure in relation to seagrass bed in Tidung Kecil Island, Kepulauan Seribu. E3S Web Conf 74: 02005. DOI: 10.1051/e3sconf/20187402005.

Honda K, Nakamura Y, Nakaoka M, Uy WH, Fortes MD. 2013. Habitat use by fishes in coral reefs, seagrass beds and mangrove habitats in the Philippines. PLoS One 8 (8): e65735. DOI: 10.1371/journal.pone.0065735.

Hylkema A, Vogelaar W, Meesters HWG, Nagelkerken I, Debrot AO. 2015. Fish species utilization of contrasting sub-habitats distributed along an ocean-to-land environmental gradient in a tropical mangrove and seagrass lagoon. Estuar Coasts 38 (5): 1448-1465.

Hyndes GA, Francour P, Guidetti P, Heck KL, Jenkins G. 2018. The roles of seagrasses in structuring associated fish assemblages and fisheries. Seagrasses of Australia. Springer, Cham.

Idrus AA, Syukur A, Zulkifli L. 2019. The diversity of fauna in mangrove community: Success replanting of mangroves species in South Coastal East Lombok. Indonesia. J Phys Conf Ser 1402 (3): 033042. DOI: 10.1088/1742-6596/1402/3/033042.

Irawan A, Supriharyono S, Hutabarat J, Ambariyanto A. 2018. Seagrass beds as the buffer zone for fish biodiversity in coastal water of Bontang City, East Kalimantan, Indonesia. Biodiversitas 19 (3): 1044-1053. DOI: 10.13057/biodiv/d190337.

Jackson EL, Rees SE, Wilding C, Attrill MJ. 2015. Use of a seagrass residency index to apportion commercial fishery landing values and recreation fisheries expenditure to seagrass habitat service. Conserv Biol 29: 899-909. DOI: 10.1111/cobi.12436.

Jackson EL, Rowden AA, Attrill MJ, Bossey SJ, Jones MB. 2001. The importance of seagrass beds as a habitat for fishery species. Oceanogr Mar Biol 39: 269-304.

Jänes H, Macreadie PI, Zu Ermgassen PS, Gair JR, Treby S, Reeves S, Emily Nicholsona E, Ierodiaconou D, Carnell P. 2020. Quantifying fisheries enhancement from coastal vegetated ecosystems. Ecosyst Serv 43: 101105. DOI: 10.1016/j.ecoser.2020.101105.

Jeyabaskaran R, Jayasankar J, Ambrose TV, Vineetha Valsalan KC, Divya ND, Raji N, Kripa V. 2018. Conservation of seagrass beds with special reference to associated species and fishery resources. J Mar 
Biol Assoc India 60 (1): 62-70. DOI: 10.6024/jmbai.2018.60.1.2038 10.

Khalaf MA, Al-Rousan S, Al-Horani FA. 2012. Fish assemblages in seagrass habitat along the Jordanian coast of the Gulf of Aqaba. Nat Sci 4 (8): 517-525. DOI: 10.4236/ns.2012.48069.

Kholis N, Patria MP, Soedjiarti T. 2017. Composition and diversity of fish species in seagrass bed ecosystem at Muara Binuangeun. Lebak. Banten. AIP Conf Proc 1862 (1): 030119. DOI: 10.1063/1.4991223.

Kiggins RS, Knott NA, New T, Davis AR. 2019. Fish assemblages in protected seagrass habitats: Assessing fish abundance and diversity in no-take marine reserves and fished areas. Aquacult Fish 5: 213-223. DOI: 10.1016/j.aaf.2019.10.004.

Kilminster KL, Forbes VR. 2014. Seagrass as an indicator of estuary condition for the Swan Canning Estuary. Water Science Technical Series WST 62. Perth, West Australia.

Kiswara W, Winardi L. 1994. Keanekaragaman dan sebaran lamun di Teluk Kuta dan Teluk Gerupuk. Lombok Selatan. J Teknologi Kelautan Nasional. 3 (1): 23-36. [Indonesian]

Kritzer JP, DeLucia MB, Greene E, Shumway C, Topolski MF, ThomasBlate J, Smith K. 2016. The importance of benthic habitats for coastal fisheries. BioScience 66: 274-284. DOI: 10.1093/biosci/biw014

Larkum AW, Kendrick GA, Ralph PJ. Eds. 2018. Seagrasses of Australia: Structure. Ecology and Conservation. Springer, Berlin.

Mishra AK, Sumantha NS. Deepak A. 2019. Boat anchors not OK: Loss of Dugong grass (Halophila ovalis) population structure in Havelock island of Andaman and Nicobar Islands, India. bioRxiv 642579. DOI: $10.1101 / 642579$

Mouillot D, Graham NA, Villéger S, Mason NW, Bellwood DR. 2013. A functional approach reveals community responses to disturbances. Trends Ecol Evol 28 (3): 167-177. DOI: 10.1016/j.tree.2012.10.004

Moussa RM, Bertucci F, Jorissen H, Gache C, Waqalevu VP, Parravicin V, Lecchini D, Galzin R. 2020. Importance of intertidal seagrass beds as nursery area for coral reef fish juveniles (Mayotte. Indian Ocean). Reg Stud Mar Sci 33: 100965. DOI: 10.1016/j.rsma.2019.100965

Moussa RM. (2018). Are mangroves important for reef fish on Mayotte Island (Indian Ocean)?. Cybium 42: 327-340. DOI: 10.26028/cybium/2018-424-004

Musembi P, Fulanda B, Kairo J, Githaiga M. 2019. Species composition. abundance and fishing methods of small-scale fisheries in the seagrass meadows of Gazi Bay. Kenya. J Indian Ocean Reg 15 (2) 139-156. DOI: $10.1080 / 19480881.2019 .1603608$

Nagelkerken I, Igulu MM, Dorenbosch M, Grol MG, Harborne AR, Kimirei IA, Mgaya YD. 2014. Mangrove habitat use by juvenile reef fish: meta-analysis reveals that tidal regime matters more than biogeographic region. PLoS One 9 (12): e114715. DOI: 10.1371/journal.pone.0114715

Neckles HA, Kopp BS, Peterson BJ, Pooler PS. 2012. Integrating scales of seagrass monitoring to meet conservation needs. Estuar Coasts 35 (1): 23-46. DOI 10.1007/s12237-011-9410-x

Newmaster AF, Berg KJ, Ragupathy S, Palanisamy M, Sambandan K, Newmaster SG. 2011. Local knowledge and conservation of seagrasses in the Tamil Nadu State of India. J Ethnobiol Ethnomed 7 (1): 37. http://www.ethnobiomed.com/content/7/1/37

Nordlund L, Erlandsson J, de la Torre-Castro M, Jiddawi N. 2010 Changes in an East African social-ecological seagrass system invertebrate harvesting affecting species composition and local livelihood. Aquat Living Resour 23 (4): 399-416. DOI: $10.1051 / \mathrm{alr} / 2011006$

Nordlund LM, Unsworth RK, Gullström M, Cullen-Unsworth LC. 2018. Global significance of seagrass fishery activity. Fish Fisher 19 (3) 399-412. DOI: 10.1111/faf.12259.

Patro S, Krishnan P, Samuel VD, Purvaja R, Ramesh R. 2017. Seagrass and salt marsh ecosystems in South Asia: an overview of diversity, distribution, threats and conservation status. In: Prusty B, Chandra R, Azeez P. (eds.) Wetland Science. Springer, New Delhi. DOI: 10.1007/978-81-322-3715-0_5.

Phinrub W, Montien-Art B, Promya J, Suvarnaraksha A. 2014. Fish diversity and fish community in seagrass beds at Ban Pak Klong. Trang Province. Thailand. Intl J Farming Allied Sci 2 (2): 197-201.

Prabhakaran MP, Nandan SB, Jayachandran PR, Pillai NGK. 2013. Species diversity and community structure of ichthyofauna in the seagrass ecosystem of Minicoy Atoll, Lakshadweep, India. Indian J Geo-Mar Sci 42 (3): 349-359.

Prasetya JD, Purwanti F. 2017. Diversity based sustainable management for seagrass ecosystem: Assessing distribution and Diversity of
Seagrass in marine protected area. Adv Sci Lett 23 (3): 2413-2415. DOI: $10.1166 / a s 1.2017 .8665$.

Pregiwati LA, Wiryawan B, Baskoro MS, Wisudo SH, Satria A. 2015. Linking indicators for ecosystem approach to fisheries management and management of marine protected area effectiveness in Anambas Island, Indonesia. Aquacult Aquarium Conserv Legisl 8 (6): 10481063.

Sari N, Syukur A, Karnan K. 2020. Kekayaan Spesies Ikan Hasil Tangkapan Nelayan Kecil pada Areal Padang Lamun di Perairan Pesisir sepanjang Pantai Lombok Tengah. Jurnal Pijar Mipa 15 (3): 252-259. DOI: 10.29303/jpm.v15i3.1811. [Indonesian]

Scapin L, Zucchetta M, Sfriso A, Franzoi P. 2018. Local habitat and seascape structure influence seagrass fish assemblages in the Venice Lagoon: The Importance of conservation at multiple spatial scales. Estuar Coasts: 41 (8): 2410-2425. DOI: 10.1007/s12237-018-0434-3.

Short F, Carruthers T, Dennison W, Waycott M. 2007. Global seagrass distribution and diversity: a bioregional model. J Exp Mar Biol Ecol 350 (1-2): 3-20.

Simanjuntak CPH, Putri AK, Rahardjo MF, Syafei LS, Abdillah D. 2020 J. Species composition and abundance of small fishes in seagrass beds of the Karang Congkak Island. Kepulauan Seribu National Park. Indonesia. IOP Conf Ser Earth Environ Sci 404 (1): 012063. DOI: 10.1088/1755-1315/404/1/012063.

Staveley TA, Hernvall P, Stjärnkvist N, van der Meijs F, Wikström SA, Gullström M. 2020. Exploring seagrass fish assemblages in relation to the habitat patch mosaic in the brackish Baltic Sea. Mar Biodiv 50 (1): 1-7. DOI: $10.1007 / \mathrm{s} 12526-019-01025-\mathrm{y}$.

Susilo ES, Sugianto DN, Munasik M, Nirwani N, Suryono CA. 2018. Seagrass parameter affect the fish assemblages in Karimunjawa Archipelago. IOP Conf Ser Earth Environ Sci 116: 012058. DOI: 10.1088/1755-1315/116/1/012058

Syukur A, Al-Idrus A, Zulkifli L. 2020. Ecotourism development based on the diversity of echinoderms species in seagrass beds on the south coastal of Lombok island. Indonesia. J Environ Sci Technol 13(2): 57-68. DOI: 10.3923/jest.2020.57.68.

Syukur A, Wardiatno Y, Muchsin I, Kamal MM. 2017. Threats to seagrass ecology and indicators of the Importance of Seagrass ecological services in the coastal waters of East Lombok. Indonesia. $\begin{array}{lllllll}\text { Amer J Environ Sci } 13 & \text { (3): 251-265. DOI: }\end{array}$ 10.3844/ajessp.2017.251.265.

Tebaiy S, Yulianda F, Muchsin I. 2017. Struktur komunitas ikan pada habitat lamun di Teluk Youtefa Jayapura Papua [Fish community structure at seagrass beds habitat in Youtefa Bay Jayapura Papua]. Jurnal Iktiologi Indonesia 14 (1): 49-65. [Indonesian]

Tsukamoto K, Keiichi M, Kurnaen SO. 1997. Fiel Guide to Lombok Island: Identification Guide to Marine Organisms In Seagrass Beds Lombok Island. Ocean Research Institut University of Tokyo, Tokyo.

Turner S, Schwarz AM. 2006. Management and conservation of Seagrass in New Zealand: an introduction. Science for Conservation 264: 1-90. DOI: 10.1016/j.ocecoaman.2014.04.032

Tuya F, Haroun R, Espino F. 2014. Economic assessment of ecosystem services: monetary value of seagrass meadows for coastal fisheries. Ocean Coast Manag 96: 181-187. DOI: 10.1016/j.ocecoaman.2014.04.032.

Unsworth RK, Cullen LC. 2010. Recognising the necessity for Indo-Pacific seagrass conservation. Conserv Lett 3 (2): 63-73. DOI: 10.1111/j.1755-263X.2010.00101.x.

Unsworth RK, McKenzie LJ, Collier CJ, Cullen-Unsworth LC, Duarte CM, Eklöf JS, Jarvis JC, Jones BJ, Nordlund LM. 2019b. Global challenges for seagrass conservation. Ambio 48 (8): 801-815. DOI: 10.1007/s13280-018-1115-y.

Unsworth RK, Nordlund LM, Cullen-Unsworth LC. 2019a. Seagrass meadows support global fisheries production. Conserv Lett 12 (1): e12566. DOI: $10.1016 /$ j.scitotenv.2018.03.315

Unsworth RKF, Garrard SL, De Leon PS, Cullen LC, Smith DJ, Sloman KA, Bell JJ. 2009. Structuring of Indo-Pacific fish assemblages along the mangrove-seagrass continuum. Aquat Biol 5: 85-95.

Unsworth RKF, Jones BL, Ambo-Rappe R, La Nafie YA, Irawan A, Hernawan UE, Moore A.M, Cullen-Unsworth LC. 2018. Indonesia's globally significant seagrass meadows are under widespread threat. Sci Total Environ 634: 279-286. DOI: 10.1016/j.scitotenv.2018.03.315.

Vieira ML M, de Lima CLA, de Souza JRB, Feitosa JLL. 2020. Effects of beach seine fishing on the biodiversity of seagrass fish assemblages. Reg Stud Mar Sci 40: 101527. DOI: 10.1016/j.rsma.2020.101527. 
Villéger S, Miranda JR, Hernández DF, Mouillot D. 2010. Contrasting changes in taxonomic vs. functional diversity of tropical fish communities after habitat degradation. Ecol Appl 20 (6): 1512-1522. DOI: $10.1890 / 09-1310.1$.

Waycott M, Duarte CM, Carruthers TJ, Orth RJ, Dennison WC, Olyarnik S, Calladinea A, Fourqureanf JW, Heck KL, Hughese Jr g.h.AR, Kendricki GA, Kenworthyj J, Shortk FT, Kendrick GA. 2009.
Accelerating loss of seagrasses across the globe threatens coastal ecosystems. Proc Natl Acad Sci USA 106 (30): 12377-12381. DOI: 10.1073/pnas.0905620106.

Yuliana E, Boer M, Fahrudin A, Kamal MM, Pardede ST. 2019. Using ecosystem approach indicators for assessing the ecological status of reef fisheries management in a marine protected area. Biodiversitas 20 (7): 1802-1810. DOI: 10.13057/biodiv/d200703. 